\title{
MORPHOMETRIC ANALYSIS OF THE INFRAORBITAL FORAMEN AND ACESSORIES FORAMINAS IN BRAZILIAN SKULLS
}

\author{
ANÁLISIS MORFOMÉTRICO DE LOS AGUJEROS INFRAORBITALES \\ Y SUPRANUMERARIOS EN CRÁNEOS DE INDIVIDUOS BRASILEÑOS
}

\author{
M. G. Elias; R. B. Silva; M. L. Pimentel; V. T. S. Cardoso; T. Rivello \& M. A. Babinski
}

ELIAS, M. G.; SILVA, R. B.; PIMENTEL, M. L.; CARDOSO, V. T. S.; RIVELLO, T. \& BABINSKI, M. A. Morphometric analysis of the infraorbital foramen and acessories foraminas in brazilian skulls. Int. J. Morphol., 22(4):273-278, 2004.

SUMMARY: The aim of the study was to establish morphometrically the infraorbital foramen (IOF) location in the sagittal and transversal plan of the skull and to analyze the variations, as well as verifying the symmetry with the contralateral IOF. 210 skulls were analyzed and as exclusion criterion, were not analyzed skulls of children. Digital paquimeter was used and had been carried through two bilateral measures: a)sagittal measure; from infraorbital margin until the superior margin of the IOF; b) transversal measure, of the lateral margin of piriformis opening until the medial margin of the IOF, using the transversal plan. These measures had formed an angle of $90^{\circ}$ between itself. The data were analyzed by the Kolmogorov-Smirnov to verify the Gaussian distribution and and Person's test to evaluate the correlation, considering significantly the differences that had presented a $\mathrm{p} \leq 0,05$. The mean \pm SD in the sagital measures were respectively; right side $6,71 \pm 1.70 \mathrm{~mm}$ and $6,83 \pm 1.83 \mathrm{~mm}$ for left side $(\mathrm{p} \leq 0.0001)$. Transversal measures were: right side $13,28 \pm 2.17 \mathrm{~mm}$ and $13,31 \pm 2.19 \mathrm{~mm}$ for left side $(\mathrm{p} \leq 0.0001)$. Were observed supranumerary foramens of the IOF, with presence of the double IOF in 50 cases, being bilateral in 08 specimens, left and right side 21 specimens for each side.The IOF are not absolutely symmetrical and may present pair bilateral and or unilateral opening. The presence of the supranumerary foraminas, as well as, the morphometrics measures in this study may intervene with the anesthesia, thus, suggest that they must be considered in the anaesthesical evaluation and be remembered during the procedures used for the localization of the forame.

KEY WORDS: 1. Skulls; 2. Infraorbital foramen; 3. Infra-orbital foramina; 4. Maxilar bone; 5. Morphometry.

\section{INTRODUCTION}

The infraorbital foramen (IOF) is situated bilaterally on the maxilar bone, down to the infraorbital border, close $1 \mathrm{~cm}$ (Gardner et al., 1988; Williams et al., 1989), but there are variations from 4 to $12 \mathrm{~mm}$ (Testut \& Latarjet,1954; Bergman et al., 1988). This foramen is directed inferior medial and in it passes the nerve and vessels which have its same name. It has a relatively big diameter if its compared to the supraorbital foramen, and can vary on the form and situation (Testut \& Latarjet; Rouvière, 1961; Hollin-shead,1982; Bolini \& Del Sol, 1990; Berge \& Bergman, 2001).

Precise knowledge of the location of reference points in this area provides important data in local anesthesia (Zide \& Swift 1998) and in maxillofacial and plastic surgical operations (Aziz et al., 2000; Hwang \& Baik, 1999; Rontal et al., 1979; Triandafilidi et al., 1990).There are several reference points on each wall with respect to infraorbital foramen, oral and maxillofacial surgery and local anesthesia (Aziz et al.; Du Tolt \& Nortje, 2003).

Several studies has been evaluated morphometric assessment of the IOF (Gruber, 1878; Gozdziewski et al., 1979; Bolini \& Del Sol; Triandafilidi et al.; Ochs \& Buckley, 1993; Chapman et al.,1995; Chung et al., 1995; Leo et al., 1995; Aziz et al.; Karakas et al., 2002), nevertheless, the results presented large variance. This foramen has been used from various reference points, e.g. to determine the morphometric variations of the orbit (Karakas et al.) and variations in size and in symmetry (Bolini \& Del Sol; Berge \& Bergman), as well as, has been reported the presence of accessory supranumerarios foramens (Gruber; Berry,1975; Bergman et al.; Aziz et al.). 
Modern surgical procedures (Karakas et al.), anesthesia (Zide \& Swift), as well as acupuncture practice (Chonghuo, 1993; Chen, 1997; Esper et al. 1997,1998), require more precise understanding of the surrounding anatomy (Bolini \& Del Sol; Karakas et al.). Data on morphometric measurements regarding reference points should reduce risks during procedures, surgical operations and anesthesia (Zide \& Swift; Karakas et al.; Du Tolt \& Nortje). Therefore, the purpose of this study was to conduct morphometric measurements of the IOF location by using the sagittal and transversal plan of the Brazilian skull as reference, as well as verifying the symmetry with the contralateral IOF.

\section{MATERIAL AND METHOD}

The protocol for the present research project has been approved by a suitably ethic committee on human research of Federal Fluminense University and the work complies with the provisions of the declaration of Helsinki in 1995 (as revised in Edinburgh, 2000). Guidelines for our internal review board were met for the observations made herein. Skulls used (210) were all in the collection of two universities of Rio de Janeiro state.

Morphometric parameters: To study the landmarks in the IOF, direct measurements were taken from dry Caucasian skulls. The measurements were made with a digital paquimeter $(\mathrm{mm})$. All measurements were performed by the authors. The measurements (bilaterally) on the IOF are shown in Fig. 1.

Sagittal measure: a sagital plain which passes by the center of the IOF, parallel to the median sagital plain was adopted. With the assistance of a digital paquimeter it was obtained the value of the distance between the infraorbital margin and the superior border of IOF.

Transversal measure: a transversal plain that passes by the center of IOF, making a $90^{\circ}$ angle with the sagital plain used for the sagital measure was adopted and with the assistance of a digital paquimeter it was obtained the value of the distance between the medial border of IOF and the piriformis opening. It was considered the position of the foramen in relation to the zigomaticmaxilar suture, when it crosses the infra-orbital margin. At this point the sagital plain that passes on it was used to classify the foramen in medial, lateral or on the same direction of this sagital plain.

The variations of situation and the quantity of opening by IOF were observed.
Exclusion criterion of the sample: It was adopted like exclusion criterion all the child skulls and the skulls which the piriformis opening was damaged, unilaterally or bilaterally.

In all the samples the presence of right maxilar joined to the left maxilar was considered indispensable to have the absolutely certainty that the studied foramens belonged to the same original skull and the statistic could express reliable results. The variables age, sex and race were not considered.

Statistical analysis: The softwareGraph Prism was used in the statistical evaluation of measurement results. From these measurements means and standard deviations $($ mean $\pm \mathrm{SD})$ were calculated. The data were analyzed by the KolmogorovSmirnov to verify the Gaussian distribution and and Person's test to evaluate the correlation, considering significantly the differences that had presented a $\mathrm{p} \leq 0,05$.

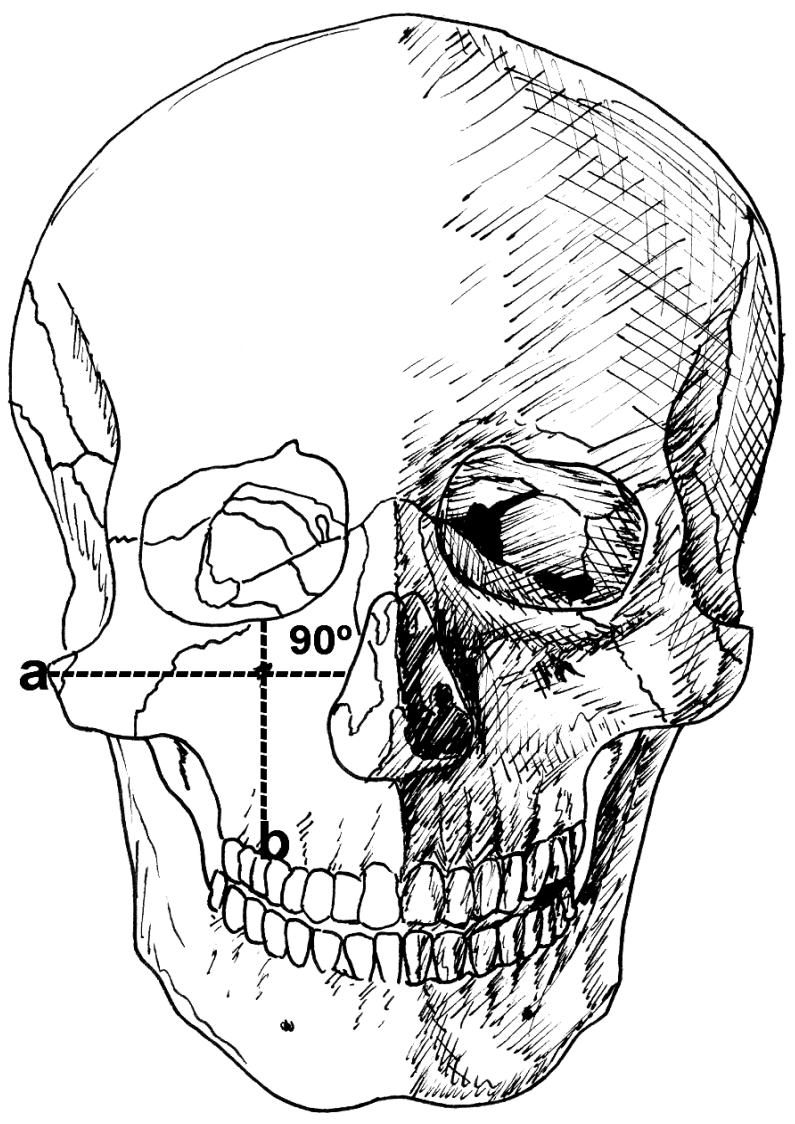

Fig. 1. Schematic draw of the morphometric parameters. a) Transversal measure: a transversal plain that passes by the center of IOF and obtained the value of the distance between the medial border of IOF and the piriformis opening making a $90^{\circ}$ angle with sagital measure; b) Sagittal measure: a sagital plain which passes by the center of the IOF, parallel to the median sagital plain and was obtained the value of the distance between the infraorbital margin and the superior border of IOF; 


\section{RESULTS}

The IOF was present in all the skulls, on the right had sagital measure of $6,71 \pm 1.70 \mathrm{~mm}$ and transversal measure of $13,28 \pm 2.17 \mathrm{~mm}$ and on the opposite site the sagital measure was $6,83 \pm 1.83 \mathrm{~mm}$ and the transversal measure was $13,31 \pm 2.19 \mathrm{~mm}$ (Table I).

Table I. Morphometric measurements ( $\mathrm{mm}$; mean $\pm \mathrm{SD}$ ) of the IOFs.

\begin{tabular}{lcc}
\hline Plan of measure & Right side & Left side \\
& Mean \pm SD & Mean \pm SD \\
Sagital & $6.71 \pm 1.70$ & $6.83 \pm 1.83$ \\
Transversal & $13.28 \pm 2.17$ & $13.31 \pm 2.19$
\end{tabular}

After having the average and the hypothesis test, it was observed that the foramen of one side had no significant difference in relation to the sagital and transversal measures averages of the opposite side. The Person's test shows the positive correlation ( $\mathrm{r} 0.48$ ) between right and left measures $(\mathrm{p}<0.0001)$ on the transversal parameter (Fig. 2). On the sagital parameter, it was observed the positive correlation either ( $\mathrm{r} 0.52$ ) between the measures on the left side in relation to the right side $(\mathrm{p}<0.0001)$ (Fig.3).

Approximately in $99 \%$ of the cases, it was observed that foramens obeyed the following relation: if one were medial (in relation to the sagital plain that passed by the zigomatic-maxilar suture when the same crossed the infraorbital margin) the other was either, or if one were lateral to the to the plain, the other was too. The only exceptions found, in number of 04 foramens, i.e., 02 skulls, in 324 analysed foramens, were of one which was medial to the plain and the other was on the direction of the plain.

After that, the following results of the foramens in relation to the median plain simmetry were found: a) medial $(60,25 \%)$; b) lateral $(08,11 \%)$; c) on the plain $(30,64 \%)$.

The standards of supranumerarios variations of IOF are presented in Table II. In this study, it was identified the opening of IOF was directed inferior medial in 65\% (137 cases) of all the analysed skulls. In $35 \%$ (73) of all cases, the opening was frontal, without the presence of "rough process" on zigomatic-maxilar suture (Table II).

Table II. Number of infraorbital acessory foraminas in skulls.

\begin{tabular}{lcc}
\hline Number of acessory foraminas & Right side & Left side \\
1 (normal) & 179 & 183 \\
2 & 21 & 21 \\
3 & 5 & 3 \\
Bilateral & & 8 \\
Total & 210 & 210 \\
\hline
\end{tabular}

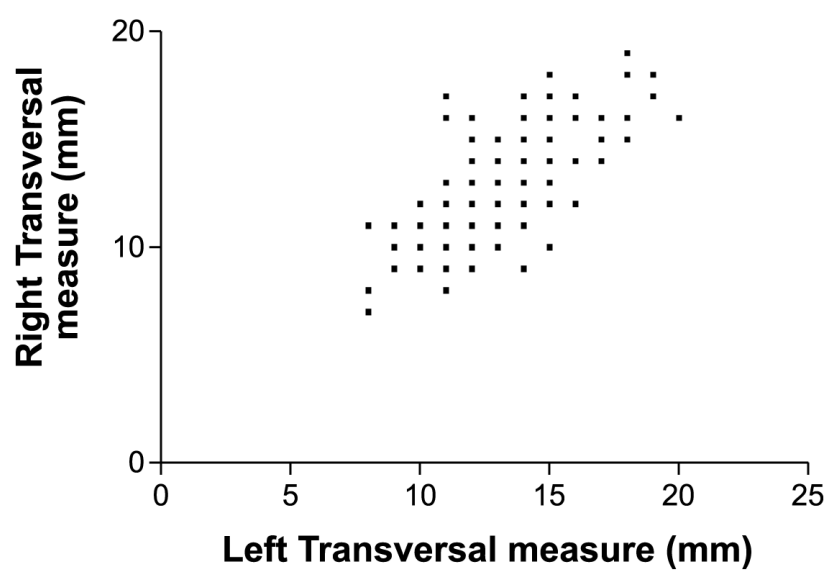

Fig. 2. The graph shows the positive correlation between right and left measures on the transversal parameter.

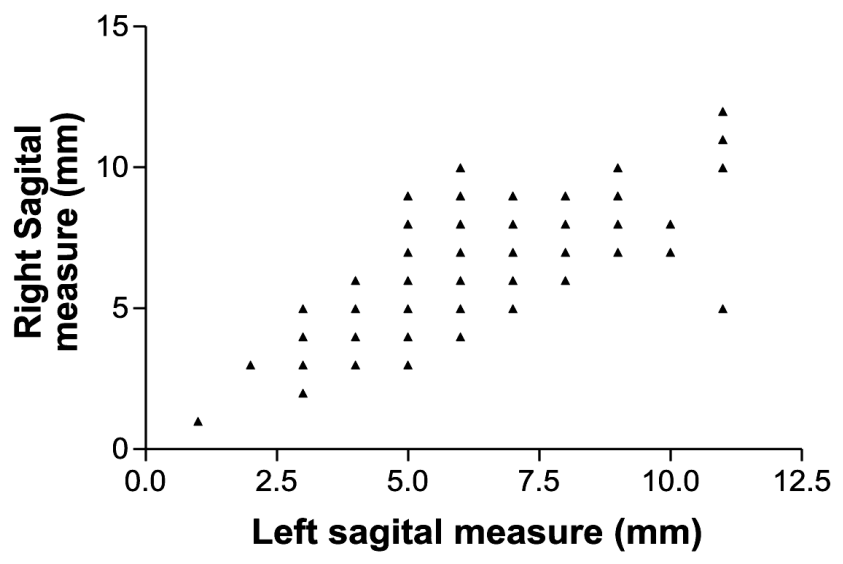

Fig. 3. On the sagital parameter, it was observed the positive correlation either between the measures on the left side in relation to the right side.

\section{DISCUSSION}

The IOF is the way to the infraorbital nerve, vessels and the knowledge of its position is very useful to the professionals who manipulate the maxilar region, e.g., in acupuncture (E2 point, Sibai) (Chonghuo; Chen; Esper et al. 1997,1998), zigoma's frature surgery (Le Fort II) (Du Tolt \& Nortje), practical of intra and extra oral anesthesia (Hollinshead; Dubrul, 1991; Figún \& Garino, 1994; Zide \& Swift).

The dentist and surgeons of head and neck have to know the exactly position of IOF (Hollinshead; Dubrul; Figún \& Garino), because the anesthetic must be put on the foramen in order that it diffuses by the canal and causes the anterior superior alveolar nerve block (that appears on the infraorbital canal of 6,0 to $10,0 \mathrm{~mm}$ before the infraorbital nerve emerges on the foramen), and in consequence, the block of the branches (which proceed of that nerve) that 
supply the central superior incisive teeth, lateral incisive and superior canine, ipsilateral to the blocked nerve (Zide \& Swift).

Figún \& Garino, point out that, the topography of IOF presents unquestionable interesting on the anesthesia practice of alveolar anterior superior nerve and the infraorbital branch, because the foramen is an excellent reference point to intraoral punctions and extra oral, 5 to $7 \mathrm{~mm}$ inferior to the infraorbital margin.

Dubrul reported about the variable distance between 6 to $8 \mathrm{~mm}$ under the inferior margin of the orbit. The authors still contribute to the description of a small "rough process" on the zigomatic-maxilar suture, and may be tangible. Bergman et al., describe a bigger variation, between 3 to $7 \mathrm{~mm}$ inferior to the infraorbital margin.

The distance between the IOF and midpoint of the inferior orbital margin has been reported to be from $4 \mathrm{~mm}$ to over $10 \mathrm{~mm}$ in several studies (Hollinshead; Bolini \& Del Sol; Triandafilidi et al.; Hindy \& Abdel-Raouf, 1993; Ochs \& Buckley; Chapman et al.; Chung et al.; Leo et al.; Aziz et al.; Karakas et al.).

Our findings of sagital measure on the studied sample point out to average of $6,71 \mathrm{~mm}$ on the right side and 6,83 $\mathrm{mm}$ on the left side with a minimum of $1 \mathrm{~mm}$ and maximum of $12 \mathrm{~mm}$ Our results show a few extremes and one of them called our attention, because the security margin to anesthetic deposition near the orbit is $1,50 \mathrm{~mm}$ (Dubrul). The left sagital measure of $1,00 \mathrm{~mm}$ and the right of $1,25 \mathrm{~mm}$ was found in a skull that escaped of the security standard. Thus we alert for this type of sporadic case, once more that it was found in only 01 from 210 skulls.

On the inferior wall of the orbit, Rontal et al. found the distance between the IOF and midpoint of the inferior orbital fissure to be $24 \mathrm{~mm}$ whereas Hwang \& Baik found it to be $26 \mathrm{~mm}$. Karakas et al. pointed that the measurement between the IOF and midpoint of the inferior orbital margin was taken as $7 \mathrm{~mm}$, i.e. similary with our study, while the distance from the same point to the midpoint of the inferior orbital fissure was $32 \mathrm{~mm}$. There were some differences on the inferior wall measurements between both Indian and Korean skulls (Hindy \& Abdel-Raouf; Chung et al.).

Monod and Wanverts (in Figún \& Garino) located an IOF on a plan (line) which is between the supraorbital incisure and the lip's comissure. According to the literature, there are some standards of location of the foramen on the surface (Dubrul); one of them is to check the line that joins the gengival margin, situated between the central and lateral incisive, medial to the fronto-zigomatic suture, a reference point easily recognized $4 \mathrm{~mm}$ over a horizontal line that passes by the lateral angle of eyelid slit. An other classic conduct suggests situate the foramen on a vertical line that joins the supraorbital incisure to the mentonian foramen, 5 to $6 \mathrm{~mm}$ under the orbital margin. We agree with Dubrul, because this method may vary on the situation.

An other important variable that we considered on the anesthetic valuation is the presence of acessory IOFs, which were studied for the first time by Gruber, who described the presence of 5 independent foramens in the end of the infraorbital canal.

In relation to the presence of acessory foramens we found double foramen in 50 cases, bilaterally in 08 specimens, both sides, 21 specimens for each side (Table II). Poirier (1912 in Bergman et al.), checked the presence of 35 double foramens, two triples and one with 4 foramens. In our study it was identified in 58 cases (Table II). It was observed that inferior medial direction may vary to a frontal opening and without the presence of "rough process" on the zigomatic-maxilar suture described by Dubrul. Aziz et al. reported multiple ipsilateral foramina were found in $15 \%$ (from 47) of cadavers. In the study by Berry, who used skulls from diferent geographic locations, multiple foramina were found in Mexicans. This may be important for surgeons because injury to any branch can result in sensory deficit and partial nerve blockade (Triandafilidi et al.; Karakas et al.). The number of infraorbital foramina could sometimes be more than one and accessory foraminas have been found in $2-18 \%$ of individuals in various populations (Berry; Gozdzieswski et al.; Bergman et al.; Williams et al, 1995).

Information on skull foramina size and symmetry (Del Sol et al., 1989) is increasingly important because of the advancements in radiologic techniques such as magnetic resonance imaging (MRI) and computed tomography (CT). These methods are making difficult diagnoses of pathologic conditions of skull foramina possible (Berge \& Bergman). In addition, the presence of acessories foraminas and the morphometric measurements showed in this study may interfere on the infiltrative anesthesia in maxila, so, we suggest that should be considered on the anaesthetic evaluation and remembered during the procedures used for localization of the foramen.

According to Karakas et al., when comparing similar studies in the literature with this study, on average there is a similarity between the sagital measurements and the data from other studies. However, there are some differences in the results of some of the reference point measurements on the transversal measurements. We consider that the diversity 
could be a result of factors such as age, sex, race pointed by Hanihara \& Ishida (2001) and differences in the reference points which are taken as criteria in the measurements.
ACKNOWLEDMENT: The authors thank's to the biomedicin student (UFF), Rafael L. R. Maciel for technical support in schematic draw (Fig.1).

ELIAS, M. G.; SILVA, R. B.; PIMENTEL, M. L.; CARDOSO, V. T. S.; RIVELLO, T. \& BABINSKI, M. A. Análisis morfométrico de los agujeros infraorbitales y supranumerarios en cráneos de individuos brasileños. Int. J. Morphol., 22(4):273-278, 2004.

RESUMEN: El objetivo del estudio fue establecer morfométricamente la localización del agujero infraorbital (FIO) en los planos sagital y transversal del cráneo y analizar las variaciones, así como verificar la simetría con el FIO contralateral. Fueron analizados 210 cráneos de individuos adultos. Utilizamos un paquímetro digital para efectuar las dos mediciones: a) sagital: del borde infraorbital hasta el borde superior del FIO; b) transversal: del borde lateral de la abertura piriforme hasta el bordemedial del FIO, utilizando el plano transversal. Estas mediciones forman un ángulo de $90^{\circ}$ entre sí. Los datos fueron analizados por Kolmogorov-Smirnov y prueba de Person para evaluar la correlación, considerando un $\mathrm{p} \leq 0.05$. La media $\mathrm{y} \pm \mathrm{SD}$ en la distancia sagital fueron en el lado derecho $6,71 \pm$ $1.70 \mathrm{~mm}$ y en el lado izquierdo $6,83 \pm 1.83 \mathrm{~mm}(\mathrm{p} \leq 0.0001)$. Las medidas transversales fueron: lado derecho $13.28 \pm 2.17 \mathrm{~mm}$ y lado izquierdo $13.31 \pm 2.19 \mathrm{~mm}(\mathrm{p} \leq 0.0001)$. Fueron observadas foraminas supranumerarias del FIO, con la presencia del IOF doble en 50 casos, siendo bilaterales en 8 especímenes izquierdos y derechos de la cara, 21 para cada lado. El FIO no era absolutamente simétrico y podía presentar el par bilateral y la abertura unilateral. La presencia de foraminas supranumerarias, como diversas medidas de este estudio, pueden interferir con la anestesia. Así sugerimos considerar estos parámetros en la evaluación anestésica y recordar las variantes durante los procedimientos usados para la localización del agujero infraorbital.

PALABRAS CLAVE: 1. Cráneo; 2. Agujero infraorbital; 3. Morfometría.

\section{REFERENCES}

Aziz, S. R.; Marchena, J.M. \& Puran, A. Anatomic characteristics of the infraorbital foramen: a cadaver study. J. Oral Maxillofac. Surg., 58:992-6, 2000.

Berge, J. K. ; Bergman, R. A. Variations in size and in symmetry of foramina of the human skull. Clin. Anat. 6:406-13, 2001.

Bergman, R. A.; Thompson, S. A.; Afifi, A. K. \& Saadeh, F. A. Compendium of Human Anatomic Variation: Catalog, Atlas and World Literature. Baltimore. Urban \& Schwarzenberg, 1988.

Berry, A. C. Factors a.ecting the incidence of non-metrical skeletal variants. J. Anat., 120:519, 1975.

Bolini, P. \& Del Sol, M. Considerações anatômicas sobre o canal e o sulco infra-orbital. Rev. Bras. Oftal. 49(2):1136,1990 .

Chapman, T.; Di Ruggiero, D.; Campbell, J. et al. Orbital osteology: a study of surgical landmarks. Laryngoscope, 105:783,1995.

Chen, E. Anatomia topográfica dos pontos de acupuntura. São Paulo, Roca, 1997.

Chonghuo, T. Tratado de Medicina Chinesa. São Paulo, Roca, 1993.
Chung, M. S.; Kim, H. J.; Kang, H. S. \& Chung, I. H. Locational relationship of the supraorbital notch or foramen and infraorbital and mental foramina in Koreans. Acta Anat. 154:162-6,1995.

Del Sol, M.; Binvignat, O. \& De Angelis, M.A. Padrões de distribuição da incisura e forame supra-orbitais. Arq. Bras. Oftal. 52:208-10,1989.

Dubrul, E. L. Sicher and Dubrul Oral Anatomy. 8th ed. Ishiyaku Euroamerica Publishers, 1991.

Du Tolt D. F. \& Nortje, C.The maxillae: integrated and applied anatomy relevant to dentistry. $S A D J ., 58(8): 325-$ 30,2003

Esper, R. S.; Yamamura, Y.; Cricenti, S. V. \& Novo, N. F. Efeitos da inserção perpendicular e oblíqua de agulhas no ponto de acupuntura E-2 (Sibai), no forame infraorbital. Rev. Paul. Acupunt., 3(2):85-8, 1997.

Esper, R. S.; Yara, J.; Yamamura, Y. \& Cricenti, S.V. Relações anatômicas do ponto de acupuntura E-2 (Sibai) localizado no forame infra-orbital. Rev. Paul. Acupunt., 4(1):19-22, 1998.

Figún, M. E. \& Garino, R. R. Anatomia odontológica funcional e aplicada. São Paulo, Panamericana, 1994. 
Gardner, E.; Gray, D. J. \& O’Hailly, R. Anatomia: estudo regional do corpo humano, 4. ed. Rio de Janeiro, Guanabara Koogan, 1988.

Gruber, W. Ein hakenformiges Fortsatzchen uber und vor dem Infraorbitalloche. Arc. Pathol. Anat. Physiol. Klin. Med., 72:494-6,1878.

Gozdziewski, S.; Nizankowski, C. \& Kindlik, R. Die morphologische Analyse des Canalis infraorbitalis und des Foramen infraorbitale beim Menschen. Anat. Anz. 145:517-27, 1979.

Hindy, A. M. \& Abdel-Raouf F. A study of infraorbital foramen, canal and nerve in adult Egyptians. Egypt. Dent. J. 39:573-80,1993.

Hollinshead, W. H. The head and neck. In: Anatomy for surgeons. Harper and Row, Philadelphia,1982.

Hwang, K. \&Baik, S. H.Surgical anatomy of Korean adults. J. Craniofac. Surg., 10:129-34, 1999.

Karakas, P.; Bozkir, M.G. \& Oguz, Ö. Morphometric measurements from various reference points in the orbit of male Caucasians. Surg. Radiol. Anat., 24(6):358-62, 2002.

Leo, J. T.; Cassell, M. \& Bergman, R. Variations in human infraorbital nerve, canal and foramen. Ann. Anat., 177: 93, 1995.

Ochs, M.W. \& Buckley, M. Anatomy of the orbit. Oral Maxillofac. Surg. Clin. North. Am., 5:419, 1993.

Rontal, E.; Rontal, M. \& Guilford, F. T. Surgical anatomy of the orbit. Ann. Otol. 88:382-6, 1979.

Rouviére, H. Anatomía humana descriptiva y topográfica. $8^{\mathrm{a}}$ ed. Madrid, Bailly-Bailliere, 1961.

Testut, L. \&Latarjet, A. Tratado de anatomía humana. Barcelona, Salvat, 1954.

Triandafilidi, E.; Anagnostopoulou, S. \& Soumila, M. The infraorbital foramen (the position of the infraorbital foramen in man). Odontostomatol. Proodos., 44:87-91, 1990.

Williams, P. L.; Warwick, R.; Dyson, M. \& Bannister, L.H. Gray's Anatomy. 37th ed. New York, Churchill Livingstone, 1989.
Williams, P. L.; Bannister, L. H.; Berry, M. M.; Collins, P.; Dyson, M.; Dussek, J. E. \& Ferguson, M. W. J. (eds): Exterior of the skull. In: Gray's anatomy. 38th. ed. Churchill Livingstone, New York, 1995.

Zide, B. \&Swift, R. How to block and tackle the face. Plast. Reconstr. Surg., 101:2018, 1998.

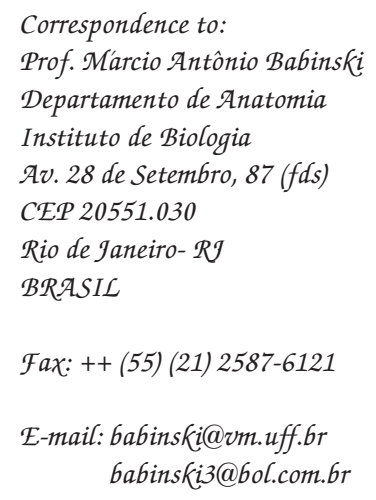

Received: 23-08-2004

Accepted: 14-10-2004 